\title{
Professional Drivers and Psychoactive Substances Consumption: First Results from Medical Surveillance at the Workplace in Italy
}

\author{
Gian Luca Rosso ${ }^{1, *}$, Mauro Feola ${ }^{2}$, Maria Paola Rubinetto ${ }^{3}$, \\ Nicola Petti ${ }^{3}$ and Lorenzo Rubinetto ${ }^{3}$ \\ ${ }^{1}$ Occupational Health Physician \\ Occupational Health Physician, S.C. Emergenza Urgenza 118, Cuneo, \\ ${ }^{2}$ Riabilitazione Cardiologica - Unità Scompenso Cardiaco, \\ Ospedale SS Trinità Fossano (CN), \\ ${ }^{3}$ Se.M. s.r.l. Medical Services, Cuneo,
} Italy

\section{Introduction}

The role played by psychoactive substances in work safety has recently become the object of increasing interest in Italy [1,2]. Particularly for professional drivers, these substances can reduce driving performance and increase the risk of accidents with fatal outcomes not only for workers but also for third parties [3]. Even if the accountability of psychotropic drugs as a cause of work accidents remains difficult to evaluate with precision, there is much evidence that the use of psychoactive substances is a major risk factor for accidents by professional drivers $[4,5]$.

Until 2008, it was not permitted to investigate the use of psychoactive substances among any worker's category in Italy. After promulgation of two recent Italian laws (the first published in the Official Gazette No. 266, November 15, 2007, and the second came into force in May 2008, the Legislative Decree 81/08), the occupational health physician (the so-called "Competent Physician") is called to assess the use of illicit drugs among professional drivers, in order to detect dependency at the workplace and improve the security and health of workers and others [6].

This Legislative Decree (DL 81/08) seemed to reiterate the importance of exceeding the simple concept of health protection of the worker, as conceived by the Legislative Decree $626 / 94$, to reach a more comprehensive analysis of all complex work activities and all special risks to security and the health of others.

A recent Study Group on Hazardous Workers, conducted in Italy (La.R.A. Group) [3], has estimated between $4 \%$ to $10 \%$ of Italian workers may be drugs consumers. There are no previous studies that have analysed this phenomenon (by testing the illegal substances or

${ }^{*}$ Corresponding Author 
their metabolite in blood or urine) in Italian professional drivers or in any other worker category.

The main purpose of this study was to investigate the prevalence of psychoactive substance usage among professional drivers by rapid urine analysis for the majority of often used illicit drugs.

\section{Materials and methods}

The study group included 198 professional drivers from 47 companies in Piedmont Region. From July to December 2008 each worker was investigated with a rapid urine screening test. In case of positive testing results the physician responsible for medical surveillance of workers defines the employee as "temporarily unfit". In order to verify this finding, the positive urine samples were sent to a specialized laboratory to confirm the previous results. Workers positive for drug tests were referred to a public health institution for diagnostic classification (drugs use, abuse or dependence) and treatment.

\subsection{Companies and categories of professional drivers involved}

Forty-seven companies (with at least one work site in Piedmont Region) were involved in the study. All of these companies have one or more workers employed as professional drivers. In our experience we have defined professional drivers as the workers involved in driving trucks or other vehicles (forklift trucks, dollies, excavators, diggers etc.). We have considered all tasks that required the driver to stay at the wheel (for more than a half working hour) with a very good reaction capacity and a high level of attention. Professional drivers were divided into three groups:

1. truckers: 69 subjects, $9 / 69$ were personal chauffeurs (only class B license required), the other 60/69 were truck drivers;

2. warehousemen: 104 workers involved in driving forklift trucks or dollies in workshop and/or depots;

3. construction workers: 25 drivers of heavy vehicles used for excavation (excavators or diggers) working in building yards.

The main features of the study population are indicated in table 1.

\subsection{Rapid urine screening tests}

According to the recent indications of the major Italian studies, we tested workers' urine for illicit substances or their metabolites using a rapid urine screening test. For the rapid urine screening test we used a multi-drug, one step, multi-line screen test device (SureStep MultiDrug, Innovacon, Inc. Manufacturer), an immunoassay test based on the principle of competitive binding. A drug, if present in the urine, reacts with its specific antibody and a visible colored line will show up in the test line region of the specific drug strip. This test was used only for the qualitative detection of the following psychoactive substances (the cut-off level is expressed in $\mathrm{ng} / \mathrm{mL}$ ): amphetamines (AMP, 500), barbiturates (BARB, 300), benzodiazepines (BZO, 300), tetrahydrocannabinol (THC, 50), methadone (MTD, 300), opiates (OPI, 300), cocaine (COC, 300), MethyleneDioxyMethaAmphetamine (MDMA, 500), phencyclidine (PCP, 25), and tricyclic antidepressants (TCA, 1000). 


\subsection{Clinical research protocol}

Upon admission, each subject was informed of the provisions related to the medical surveillance of drug dependency at the workplace. At least one month before the screening test, it was explained to each worker that the occupational health physician would have to investigate the use of illicit drugs among professional drivers. It was also explained that the identification of positive rapid urine screening test would cause a temporarily unfit judgment to any complex working activities (such as professional driving) and may also cause a temporary loss of job.

For the achievement of these aims we have adopted the following procedural algorithm (figure 1):

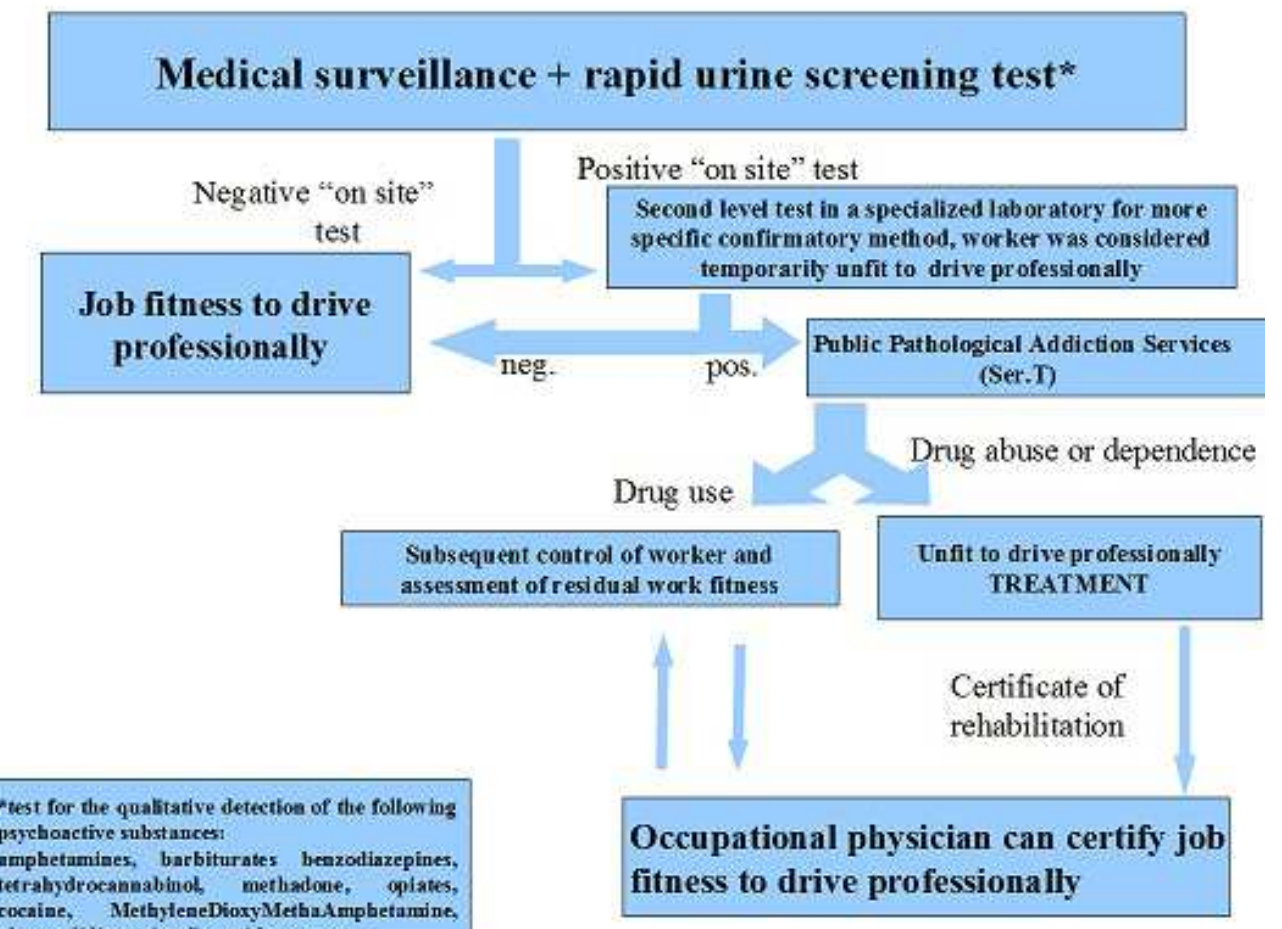

Fig. 1. Procedural algorithm adopted

- Communication stage: the initial phase, in which each worker was informed that the identification of positive rapid urine screening test would cause a temporarily unfit judgment to any complex working activities (such as professional drive) and may also cause a temporary loss of job.

- Samples collection stage for first level tests: professional drivers were convened with a written notice only 1 day before the analysis (in order to avoid intentional suspensions of drugs assumption). During medical surveillance of workers the occupational physician analyzed urine samples from employees with the rapid screening test. 
- Stage of urine sample preservation for second level tests: only in the case of a positive screening test would the physician seal the urine sample (in the presence of the worker) and send it to a specialized laboratory to obtain a confirmed result.

- "Job fitness" stage: workers positive for drug tests were considered temporarily unfit to drive professionally and referred to a public Pathological Addiction Services (Ser.T.) for diagnostic classification (drugs use, abuse or dependence) and treatment.

\subsection{Statistical analysis}

Continuous variables are summarized by the mean (M) and the standard deviation (S.D.). Two independent samples t-test (unpaired) was used to compare differences between variables in professional drivers with positive or negative test. Categorical variables were analyzed using the chi-square test. All probability values were two-tailed and differences were considered significant with a $\mathrm{p}$ value $\leq 0.05$.

\section{Results}

In the period from July until December 2008 rapid urine screening test was carried out on 198 workers. All subjects were professional drivers (employees who spend more than half the time at the wheel): 69 (34.8\%) truck drivers or personal chauffeurs, 104 (52.6\%) workers involved in drive machinery for the handling of goods (lift truck), and 25 (12.6\%) drivers of machinery for the moving of earth.

Main results and features of the study population are indicated in table 1.

We found 14 positive rapid urine screening test $(7.1 \%)$ and these results from the screening stage were verified by specialized laboratories. The results of the second level tests are indicated in table 2 .

One $(7.1 \%)$ of the positive test was not confirmed and one $(7.1 \%)$ was positive only for benzodiazepines. Considering only illegal substances were detected, $6.1 \%$ of all drivers tested positive (12/198 professional drivers). Cannabis (THC) was the most frequently detected substance (seen in $83.3 \%$ of cases), after that was the methadone $(16.7 \%)$ and then cocaine $(8.3 \%)$. In only one subject more than one substance was found (THC and COC).

Five (41.7\%) were ex drug-addicts and public Pathological Addiction Services (Ser.T.) had previously followed them. It is important to emphasize that these workers had not declared their ex addiction until they tested positive at the screening test. As for the other 7 (58.3\%), it was the first time they tested positive and, on the basis of history and clinical examination, an addiction was excluded. Despite those considerations, all 12 positive workers underwent assessment at Ser.T (as indicated by Italian laws) for diagnostic classification (drugs use, abuse or dependence, but on the basis of illicit drugs values, $2 \%$ of professional drivers investigated were assumed to be drug abusers) and treatment.

We have not found significant differences in illicit drug consumption between the three groups analyzed. A trend in favour of attitude to drug assumption among workers involved in drive machinery for the handling of goods emerged.

In our study professional drivers from 31 to 35 years old have a higher risk to be consumers than younger drivers $(p=.015)$, as shown in table 3 . However, it should be noted that the 


\begin{tabular}{|c|c|c|c|c|}
\hline & & $\begin{array}{c}\text { Truck drivers or } \\
\text { personal } \\
\text { chauffeurs }\end{array}$ & $\begin{array}{c}\text { Drivers of } \\
\text { machinery for the } \\
\text { handling of goods }\end{array}$ & $\begin{array}{c}\text { Drivers of } \\
\text { machinery for the } \\
\text { moving of earth }\end{array}$ \\
\hline \multicolumn{2}{|c|}{ Age [years; $M$ (S.D.)] } & $41(10.1)$ & $40(8.6)$ & $40(12.8)$ \\
\hline \multirow{4}{*}{$\begin{array}{l}\text { Distribution } \\
\text { by age } \\
\text { groups }\end{array}$} & 18 - 30 years & 13 & 24 & 7 \\
\hline & 31 - 40 years & 15 & 41 & 7 \\
\hline & 41 - 50 years & 28 & 30 & 6 \\
\hline & 51 - 71 years & 13 & 9 & 5 \\
\hline \multicolumn{2}{|l|}{\begin{tabular}{|l|} 
Total \\
\end{tabular}} & 69 & 104 & 25 \\
\hline \multicolumn{2}{|l|}{ Sex } & $68 \mathrm{M} \quad 1 \mathrm{~F}$ & $101 \mathrm{M} \quad 3 \mathrm{~F}$ & $25 \mathrm{M} \quad$ OF \\
\hline \multicolumn{2}{|c|}{$\begin{array}{l}\text { Mean duration of } \\
\text { employment [years; } M \text { (S.D.)] }\end{array}$} & $13(10.5)$ & $11(6.7)$ & $14(14)$ \\
\hline \multirow{4}{*}{$\begin{array}{l}\text { Educational } \\
\text { level }[n(\%)]\end{array}$} & Elementary & $3(4.4 \%)$ & $1(0.9 \%)$ & $1(4 \%)$ \\
\hline & Middle school & $53(76.8 \%)$ & $65(62.5 \%)$ & $15(60 \%)$ \\
\hline & High school & $13(18.8 \%)$ & $37(35.7 \%)$ & $9(36 \%)$ \\
\hline & University & - & $1(0.9 \%)$ & - \\
\hline \multirow{4}{*}{$\begin{array}{l}\text { Positivity "on } \\
\text { site" tests, } \\
\text { confirmed at } \\
\text { second level } \\
\text { tests }[n(\%)]\end{array}$} & THC & $2(2.9 \%)$ & $8(7.7 \%)$ & - \\
\hline & $\mathrm{COC}$ & $1(1.4 \%)$ & - & - \\
\hline & MTD & $1(1.4 \%)$ & $1(1 \%)$ & - \\
\hline & $\mathrm{BZO}$ & $1(1.4 \%)$ & - & - \\
\hline
\end{tabular}

$\mathrm{M}=$ Mean and S.D.=standard deviation

Table 1. Main features of the study population for three professional driver categories for age distribution, sex, emplyment duration, education level and positivity

\begin{tabular}{|l|c|c|c|}
\hline Test & $\begin{array}{c}\text { Positive } \\
{[\boldsymbol{n}(\mathbf{\%})]}\end{array}$ & $\begin{array}{c}\text { Concentrations } \\
{[\mathbf{n g} / \mathbf{m l} \text { (S.D.) }]}\end{array}$ & $\begin{array}{c}\text { Cut-off } \\
\mathbf{( n g / m L )}\end{array}$ \\
\hline Tetrahydrocannabinol (THC) & $10(5.1 \%)$ & $62.2(64)$ & 15 \\
\hline Cocaine (COC) & $1(0.5 \%)$ & 4603 & 100 \\
\hline Benzodiazepines (BZO) & $1(0.5 \%)$ & - & - \\
\hline Methadone (MTD) & $2(1 \%)$ & $2542(984.3)$ & 100 \\
\hline
\end{tabular}

Table 2. Drug types and values for the professional drivers that tested positive.

mean age of the study population was around 40 years old and the largest group was between 31 and 50 years old. The distribution of positive tests by age groups is as follows:

- $\quad$ under 31 years: 44 subjects, none tested positive,

- $\quad$ age between 31 and 40 years: 8 out of 63 positive for THC, COC and MTD,

- $\quad$ age between 41 and 50 years: 64 workers, two positive to THC,

- $\quad$ over fifty years: 27 subjects, two positive to THC and MTD.

In our sample the mean age of THC consumers is 38.3 (S.D. 6.93), this result is apparently in contrast with data from international literature, in particular a French study showed that THC use by truck drivers was higher in younger workers (age between 18 and 25 years) [7]. With the exception of one subject (THC positive with a value of $238 \mathrm{ng} / \mathrm{ml}$ ), the other nine were feebly positive to THC, in fact all THC urine values were beneath the $80 \mathrm{ng} / \mathrm{ml}$. 
One female worker proved to be positive to THC, despite the small number of women enrolled.

We have not found significant differences in the mean duration of employment or educational level between workers that tested positive. However, in our sample, workers who were positive seemed to have a mean duration of employment lower than the negative ones (see table 3).

\begin{tabular}{|c|c|c|c|}
\hline AGE & NEGATIVE & POSITIVE & $\mathrm{P}$ \\
\hline$\leq 30$ years & 44 & 0 & \multirow{2}{*}{$0.015^{*}$} \\
\hline $31-35$ years & 29 & 6 & \\
\hline $31-35$ years & 29 & 6 & \multirow[b]{2}{*}{0.122} \\
\hline$\geq 36$ years & 113 & 6 & \\
\hline$\leq 30$ years & 44 & 0 & \multirow{2}{*}{0.29} \\
\hline$\geq 36$ years & 113 & 6 & \\
\hline DURATION OF & \multirow[b]{2}{*}{$11.3(9.6)$} & \multirow[b]{2}{*}{$8.1(6.7)$} & \multirow[b]{2}{*}{0.15} \\
\hline $\begin{array}{l}\text { EMPLOYMENT } \\
\text { [years; } M \text { (S.D.)] }\end{array}$ & & & \\
\hline $\begin{array}{c}\text { MEAN AGE } \\
\text { [years; } M \text { (S.D.)] }\end{array}$ & $39.1(9.9)$ & $39(7.6)$ & 0.9 \\
\hline
\end{tabular}

* significant

Table 3. Age and duration of employment of the study subjects

For the professional driver who was found positive to BZN, we have not adopted the procedural algorithm in figure 1, but we have decided to intensify the medical surveillance of the workers. None of 198 subjects tested positive to TCA or BARB.

The 12 workers identified positive to the rapid urine screening test, were judged to be temporarily unfit to drive professionally and, three of those $(25 \%)$ suffered a temporary loss of their job, the other nine were placed in other working activities. This consequence is related to the small size of the companies within the study (such as many of Italian transportation companies) which had great difficulties placing their professional drivers in another working activity [6].

Finally, positive cases were dispersed between the 47 companies, without bias towards any one driving group that may suggest a critical situation in one or more companies.

\section{Discussion}

The most significant result in this study is the prevalence of employees (more than 6\%, between those involved in complex working activities) that, with different modalities, have a problem of substances consumption. Nevertheless, the analysis of the current findings requires cautions: in fact, if we exclude the workers who tested positive for THC only (in 
low concentrations) or BZN, we would be left with a small group of four professional drivers (2\%) who tested positive to COC or MTD or THC (in high concentrations). These four workers are particularly dangerous for themselves and also for third parties. On the other hand, we should not underestimate the current results because, despite all 198 workers being informed beforehand of the provisions related to screening test, 12 employees were not able to stop their consumption of illicit drugs.

Cannabis was the most frequently detected substance (seen in $83.3 \%$ of positive cases). This observation matches the previous studies conducted in other countries, which have indicated cannabis as the principal illicit drug consumed by drivers [8,9]. Moreover, the distribution of illicit drugs among professional drivers is similar to a previous published French experience [7].

The major limitation of this study is the small population examined, which may limit generalization of the findings.

In our study, the risk for consumption of illicit drugs between professional drivers aged 31 and 40 years old seemed to be higher. This result may be due to the fact that younger workers are probably concerned about losing their job (they usually have atypical employment contracts or they work without contracts). However these results confirm that in Italy, the problem concerning substance consumptions in complex working activities is not restricted to a certain age of workers but actually involves all age groups. It should be noted that our sample was relatively small; therefore we did not find significant differences in mean duration of employment and/or educational level between workers who tested positive and negative ones.

The rapid urine screening test, which we have used in our study, was a useful tool. The two cases, in which the test "on site" was not confirmed by specialized laboratory, are probably due to the lack of physician experience which may have caused the erroneous reading. It is also important to point out that a positive result does not indicate intoxication and does not mean that behavioral abilities are impaired during working activity. It should be recalled that there is no clear association between occasional use of psychoactive substances like THC and increased risk for work accidents; however, cannabis use can amplify the other risk factors associated with accidents and injuries [10].

In the current study, $25 \%$ of worker who tested positive have suffered a temporary loss of their job, but none of those was defined with certainty as a drug abuser. This situation is due to the fact that the 47 companies in the study are small in size (as are many of the Italian transportation companies) and they have difficulties placing a professional driver in another working activity [11]. Furthermore, at the end of this study only one out of 12 professional drivers was evaluated by Ser.T, because the time it takes to call him in requires several weeks.

To our knowledge, this is the first Italian research study that has investigated the use of psychoactive substances among professional drivers using urine analysis to detect many of the major illicit drugs. Our results highlight that the problem of drug consumption among professional drivers in Italy is real. Health education (with new prevention programmes able to involve all age groups) and medical surveillance (with workplace drug-testing) may improve the safety of workers and also third parties. 


\section{Acknowledgment}

This study was totally self supporting. Part of the results of this article has been presented at the national congress of SIMLII held in Turin in 2011.

We thank the technicians and physician of the S. Luigi Hospital Orbassano (TO) for the collaboration and help confirming the rapid urine tests.

\section{References}

[1] M.M. Ferrario, P. Apostoli, P.A. Bertazzi, G. Cesana, G. Mosconi, L. Riboldi, Occupational medicine faces new health challenges: the example of alcohol dependence, Med. Lav. 98 (2007) 355-373.

[2] F. Spigno, N. Debarbieri, F. Traversa, Workplace and psychoactive substances dependence: certificate of eligibility for work and perspectives of prevention in the light of recent innovative regulations, G. Ital. Med. Lav. Erg. 29 (2007) 158-165.

[3] N. Magnavita, A. Bergamaschi, M. Chiarotti, A. Colombi, B. Deidda, G. De lorenzo, Workers with alcohol and drug addiction problems Consensus Document of the Study Group on Hazardous Workers, Med. Lav. 99 (2008) 3-58.

[4] I.M. Bernhoft, A. Steentoft, S.S. Johansen, N.A. Klitgaard, L.B. Larsen, L.B. Hansen, Drugs in injured drivers in Denmark, Forensic Sci. Int. 150 (2005) 181-189.

[5] J.G. Bramness, S. Skurtveit, J. Morland, Clinical impairment of benzodiazepines-relation between benzodiazepine concentrations and impairment in apprehended drivers, Drug Alcohol Depend. 68 (2002) 131-141.

[6] G.L. Rosso, R. Zanelli, S. Bruno, M. Feola, M. Bobbio, Professional driving and safety, a target for occupational medicine, Med. Lav. 98 (2007) 355-373.

[7] L. Labat, B. Fontaine, C. Delzenne, A. Doublet, M.C. Marek, D. Tellier, M. Tonneau, M. Lhermitte, P. Frimat, Prevalence of psychoactive substances in truck drivers in the Nord-Pas-de-Calais region (France), Forensic Sci. Int. 174 (2008) 90-94.

[8] B.M. Appenzeller, S. Schneider, M. Yegles, A. Maul, R. Wennig, Drugs and chronic alcohol abuse in drivers, Forensic Sci. Int. 155 (2005) 83-90.

[9] O.H. Drummer, J. Gerostamoulos, H. Batziris, M. Chu, J.R. Caplehorn, M.D. Robertson, P. Swann, The incidence of drugs in drivers killed in Australian road traffic crashes, Forensic Sci. Int. 134 (2003) 154-162.

[10] E.J. Wadsworth, S.C. Moss, S.A. Simpson, A.P. Smith, A community based investigation of the association between cannabis use, injuries and accidents, J. Psychopharmacol. 20 (2006) 5-13.

[11] G.L. Rosso, Prevention of road accidents involving heavy vehicles, what role for occupational medicine?, G. Ital. Med. Lav. Ergon. 30 (2008) 309-311. 


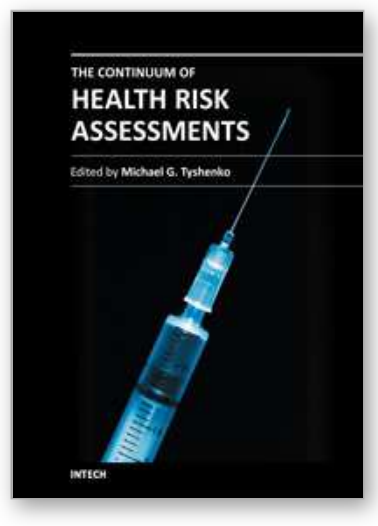

\author{
The Continuum of Health Risk Assessments \\ Edited by Dr. Michael G. Tyshenko
}

ISBN 980-953-307-582-7

Hard cover, 194 pages

Publisher InTech

Published online 16, May, 2012

Published in print edition May, 2012

This book presents a collection of health risk assessments for known and emerging hazards that span a continuum. Case studies for existing health risks include psychoactive drug usage in delivery truck drivers and using look-back risk assessment for accidental syringe re-use in healthcare settings. Case studies for emerging risks include precautionary actions to safeguard blood supplies; nanoparticle deposition in the lung; and the epistemic issues surrounding genetically modified organism risk assessments. The final section of the book deals with advancing health risk assessment analyses through a post-genomics lens and provides case studies on personalized genomics, new data analyses and improving in silico models for risk assessment. These case studies provide much insight into the ongoing evolution of health risk assessments.

\title{
How to reference
}

In order to correctly reference this scholarly work, feel free to copy and paste the following:

Gian Luca Rosso, Mauro Feola, Maria Paola Rubinetto, Nicola Petti and Lorenzo Rubinetto (2012). Professional Drivers and Psychoactive Substances Consumption: First Results from Medical Surveillance at the Workplace in Italy, The Continuum of Health Risk Assessments, Dr. Michael G. Tyshenko (Ed.), ISBN: 980953-307-582-7, InTech, Available from: http:/www.intechopen.com/books/the-continuum-of-health-riskassessments/professional-drivers-and-psychoactive-substances-consumption-risk-assessment-at-theworkplace-in-it

\section{INTECH}

open science | open minds

\section{InTech Europe}

University Campus STeP Ri

Slavka Krautzeka 83/A

51000 Rijeka, Croatia

Phone: +385 (51) 770447

Fax: +385 (51) 686166

www.intechopen.com

\section{InTech China}

Unit 405, Office Block, Hotel Equatorial Shanghai

No.65, Yan An Road (West), Shanghai, 200040, China

中国上海市延安西路65号上海国际贵都大饭店办公楼 405 单元

Phone: +86-21-62489820

Fax: $+86-21-62489821$ 
(C) 2012 The Author(s). Licensee IntechOpen. This is an open access article distributed under the terms of the Creative Commons Attribution 3.0 License, which permits unrestricted use, distribution, and reproduction in any medium, provided the original work is properly cited. 